

\author{
ADVANCED INTERNATIONAL JOURNAL OF \\ BUSINESS, ENTREPRENEURSHIP AND SMES \\ (AIJBES) \\ www.aijbes.com
}

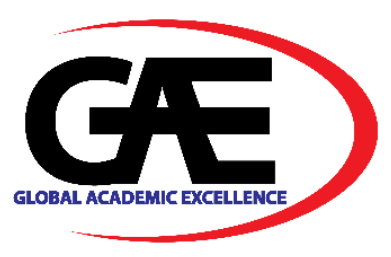

\title{
ANALYSIS OF CONSUMER PURCHASE BEHAVIOR OF NON- AUTHORIZED (NON BPOM) FACE MASK IN INDONESIA LOCAL PRODUCT
}

\section{Grace Olivia $^{1}$}

1 School of Business and Management, Institut Teknologi Bandung

Email: grace_olivia@sbm-itb.ac.id

\section{Article Info:}

\section{Article history:}

Received date: 08.06 .2021

Revised date: 16.06 .2021

Accepted date: 28.07.2021

Published date: 01.09.2021

\section{To cite this document:}

Olivia, G. (2021). Analysis of Consumer Purchase Behavior of NonAuthorized (Non BPOM) Face Mask in Indonesia Local Product. Advanced International Journal of Business, Entrepreneurship and SMEs, 3 (9), 67-90.

DOI: $10.35631 /$ AIJBES.39006.

This work is licensed under $\underline{\mathrm{CC} B Y}$ 4.0

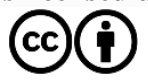

\begin{abstract}
:
The face mask trend has developed as a new trend in the Indonesian cosmetics industry lately. Due to the high demand for face masks, Indonesian mask manufacturers are innovating to create local face masks. Unfortunately, several non-authorized local face mask products have been traded on the market with a fairly high level of sales. This study aims to determine consumer awareness of the safety of non-authorized local face masks, and also the relationship between non-authorized local face mask factors. The data were collected by semi-structured interviews and online survey methods towards non-authorized local face mask users. Open coding will be used to process the qualitative data collected during the semi-structured interview, while the quantitative data were analyzed through PLS-SEM to analyze the relationship between the variable of non-authorized proneness, subjective norms, ethical judgments, and product evaluation that influence consumers buying behavior and their purchase decision towards non-authorized local face masks. The result indicates that there is a significant influence between the factor of non-authorized proneness, subjective norms, ethical judgments, and product evaluation that influence consumers buying behavior and their purchase decision for non-authorized local face masks. The findings of the study will be useful in raising consumer and business awareness of the risks of non-authorized local face masks. Furthermore, the results of this study will be used to help develop a demarketing strategy for non-authorized local face masks.
\end{abstract}

Keywords:

Non-authorized Local Face Mask, Consumer Behavior, Purchase Decision, Consumer Awareness, Demarketing 
Volume 3 Issue 9 (September 2021) PP. 67-90 DOI 10.35631/AIJBES.39006

\section{Introduction}

Our skin reflects our origin, lifestyle, age, and state of health. Skin health is an important aspect not only for appearance but more important as an aspect of aesthetics and an essential part of the human body. Skin needs to be cared for and maintained by using a skincare routine. Skin Care Routine is an important process of taking care of the skin to ensure the skin is in good condition and healthy (Noor et al., 2018). Different types of skin have different routines and procedures to be followed. Human skin is classified and categorized based on several features such as dry or oily, sensitive or resistant, pigmented or non-pigmented, and wrinkled or nonwrinkled (Baumann, 2008)

Increasingly, people care about the health of their skin. Because of that, the need for cosmetic and body care products is increasing so that it also affects the growth in the beauty industry. Indonesia itself has also experienced very rapid growth in the beauty sector, even in second place with the largest number of cosmetic consumption after India (Elwafi, 2020).

As reported by the Ministry of Industry, that the growth of cosmetics in 2019 has grown by $7 \%$ and will target more than $9 \%$ by 2020 which relies on expanding various types of cosmetics and personal care. The growth of cosmetics in Indonesia is shown in this graph:

\section{Figure 1: Beauty and Personal Care Growth in Indonesia (Statista.com)}

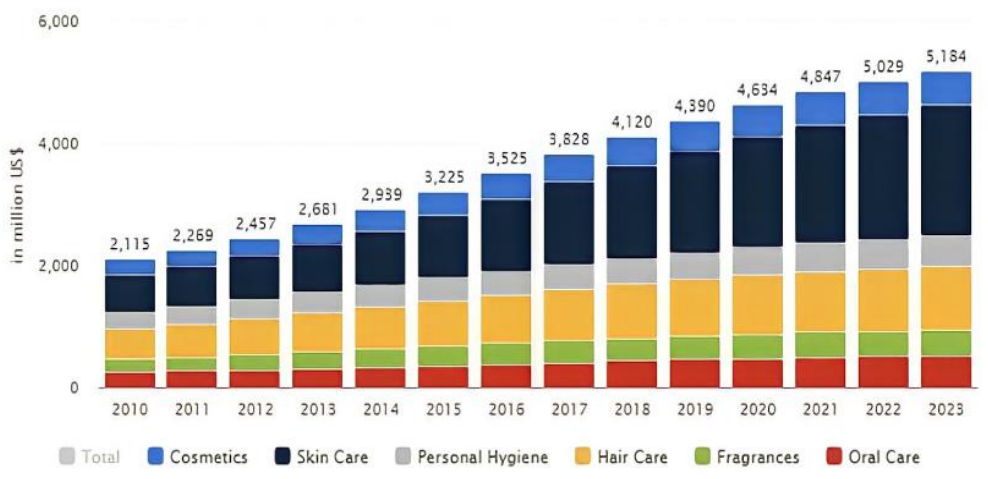

Along with the times and the trend of beauty enthusiasts, the cosmetic industry has also begun to innovate in creating facial care products, one of which is face masks. Starting from the South Korean trend, the face mask industry has grown in popularity in recent years. The trend of using face mask treatments has become one of the key products in the skincare routine in South Korea, South East Asia, and the Far East Asian countries (Bhandalkar and Deshmukh, 2019).

This face mask trend has developed as a new trend in the Indonesian cosmetics industry, gaining popularity through the support of beauty influencers and extensive marketing campaigns on social media (Konstantopoulou et al., 2019). As shown in Figure 1 beauty and personal care in Indonesia are increasing every year. Using face masks has become a necessity nowadays as routine care that cannot be missed, especially for women (Greenwood, 2020). This certainly makes the demand for face masks in Indonesia increase (Tempo, 2020). This growth was driven by market demand from the domestic and export markets in line with the trend of people starting to pay attention to these facial care products (Kunjana, 2018). 
Volume 3 Issue 9 (September 2021) PP. 67-90

DOI 10.35631/AIJBES.39006

Due to the high face mask business in Indonesia, mask manufacturers in Indonesia are innovating to create local face masks (Indonesian Ministry of Industry, 2020). Local face masks are face masks that come from local brands and face mask manufacturers from Indonesia. Popular local face mask brands from Indonesia such as Mustika Ratu, Emina, Luxcrime, and many popular local beauty brands that produce beauty face masks (Firdha, 2020). The quality of these local face masks is not inferior to imported face masks from foreign brands and is ready to compete in the market (Febriyana,2017). Along with the changing paradigm of a society that cares more about the environment, local face masks in Indonesia have been developed using natural ingredients (Wathoni et al., 2018). Not a few have created organic face masks with various variants such as coffee, green tea, saffron, and many more (Gabriel, 2008). Apart from being environmentally friendly, this face mask made from natural and organic ingredients has many benefits for facial skin health (Nilforoushzadeh et al., 2018). These local face masks are easy to find and are widely sold in various online shops at quite affordable prices, especially for students who are their main target.

Unfortunately, there are local face masks that already have authorized and many of local face masks non-authorized. Meanwhile, one indicator of a marketable beauty product must be authorized. The requirements for authorized beauty products must have been lab tested and obtained a distribution permit from the BPOM. Badan Pengawas Obat dan Makanan (BPOM) is the highest licensing agency for the distribution of food supplements, medicines and cosmetics in Indonesia. Products authorized are guaranteed safe and are always carried out by surveys both for their products and direct random surveys in the field to ensure their safety.

But in conditions that are non-authorized, many local face masks have been traded on the market with a fairly high level of sales. Preliminary research was conducted in the form of semistructured interviews with four consumers who have purchased a non-authorized local face mask. Based on the results of preliminary research, it shows that consumers do not really pay attention to the authorized or BPOM approved factors on the purchased local face masks. Most consumers who are respondents to preliminary research also use a non-authorized local face mask and do not know about the side effects of these masks, thus indicating that there is still a lack of consumer awareness about the safety of a non-authorized local face mask. In fact, one of the requirements for authorized local face mask products to be distributed on the market must be lab tested and obtain a distribution permit from the Indonesian Food and Drug Administration Agency to ensure their safety before being used by consumers. There are still many consumers buying these non-authorized local face mask products, thus indicating that consumers are not aware of the safety of non-authorized local face masks. There are several factors that influence consumer buying behavior towards non-authorized local face masks such as, non-authorized proneness, subjective norms, ethical judgments, and product evaluation (Sharma and Chan, 2016). The factors previously by Sharma and Chan (2016) mentioned can influence purchasing decisions from consumers as well. Consumer buying behavior also has a relationship with purchase decisions, where consumer buying behavior is the process by which customers make purchase decisions, use, and set purchased goods and services, including factors that affect purchase decisions and product use (Lamb et al., 2010). The factors mentioned earlier by Sharma and Chan (2016) will support the demarketing strategy for non-authorized local face masks. Demarketing can be defined as the feature of marketing that deals with temporarily or permanently discouraging consumers in general or a certain customer segment in particular (Kotler and Levy, 1971). Demarketing consists of actions for persuading consumers to change their perceptions and habits toward certain products. (Wall, 2007). The purpose of this study is to find out the level of consumer awareness of the safety of non-authorized local face masks, 
Volume 3 Issue 9 (September 2021) PP. 67-90 DOI 10.35631/AIJBES.39006

and the relationship between the factor of non-authorized proneness, subjective norms, ethical judgments, and product evaluation that influence consumers buying behavior and their purchase decision for non-authorized local face masks. Furthermore, the findings of this study will inform the design of a demarketing strategy for non-authorized local face masks.

\section{Literature Review}

\section{Non-authorized Face Mask}

Face masks have become an important and growing segment of the beauty care market (Clin et al.,2019) Facial masks are accessible and easy to apply beauty products that show an instant effect on the skin (Nilforoushzadeh et al.,2018). According to Nilforoushzadeh et al. (2018), there are four groups of parts of face masks: (a) sheet masks; (b) peel-off masks; (c) rinse masks; and (d) hydrogel. In fact, face beauty masks can enhance the skin's self-defense ability, thereby protecting the skin ecosystem more effectively and actively (Morganti et al., 2020). Innovative and effective face masks can improve consumer appearance and physical health, reduce stress conditions, and match their skin type and lifestyle (Morganti et al., 2020).

The global face masks market was worth around 32.76 billion dollars in 2018, and it was expected to grow to over 50.9 billion dollars by 2025 (Statista, 2020). In Indonesia, face mask products penetration increased by just over $8 \%$ in 2019. According to data from the Indonesian Ministry of Industry, the average age of Indonesians is between 16 and 24, putting them in the millennial and Gen $\mathrm{Z}$ segments, which allows the face mask industry to grow. Due to the high demand for face masks, there are many non-authorized local face masks in the market. According to Kompas (2020), there are already many non-authorized local face masks that are widely sold through social media or online e-commerce. Moreover, high sales and virality levels on social media affect the value of these non-authorized local face masks.

\section{Non-authorized Proneness}

Non-authorized proneness can be defined as the nature of consumers who are relatively stable in terms of a general tendency to choose, like, buy and use non-authorized products (Sharma and Chan, 2011). Moreover, cognitive and socio-normative aspects, prone to being nonauthorized are intrinsic characteristics of consumers who take advantage of the affective and behavioral aspects of purchasing non-authorized goods (Sharma and Chan, 2011). In fact, there is a positive relationship between non-authorized prone to purchase intentions of nonauthorized local face masks (Klarmann et al., 2012; Michaelidou and Christodoulides, 2011; Phau et al., 2013).

Consumers try to reduce the perception of this phenomenon by changing their attitudes towards non-authorized products with a biased evaluation process that considers non-authorized products to be better than the original (de Matos et al., 2007) and beneficial evaluations that make them feel less guilty when buying non-authorized products (Sharma and Chan, 2011). In fact, non-authorized product owners also evaluate products better (Bian and Moutinho, 2011) and consumers do not see non-authorized products as being lower than the original version because of their positive attitude regarding non-authorized local face mask products (Nia and Zaichkowsky, 2000). 


\section{Subjective Norms}

Subjective norms consist of normative beliefs and motivation to comply with beliefs as expectations represented by relevant others (Fishbein and Ajzen, 1975). Subjective norms can be defined as an individual's motivation to follow personal expectations that are important to the individual, such as peers and superiors (Taylor \& Todd, 1995; Venkatesh, Morris \& Ackerman, 2000). According to the theory of reasoned action (TRA), it explains that each individual and subjective norms can influence behavioral intentions which may predict actual behavior (Fishbein and Ajzen, 1975). It reflects the social pressure a person feels when performing a certain behavior (Kim \& Chung, 2011). Subjective norms can be assumed to have two interacting components such as beliefs about how other people, which may be in some ways important to that person, want them to behave (normative beliefs) and positive and negative judgments about each belief (Ajzen, 1991). According to previous study, it has been shown that non-authorized proneness can influence consumers towards non-authorized product preferences, to help ensure consistency between personality traits, subjective norms, and usual behavior patterns (Klarmann et al., 2013; Michaelidou and Christodoulides, 2011; Phau et al., 2014). Non-authorized local face masks purchases that are not deceptive are deliberate behavior (on a whim) (Stöttinger and Penz, 2015) and that consumers perceive it as normatively correct behavior due to subjective norms that benefit their peers (Albers-Miller, 1999) and society area (Jirotmontree, 2013).

Consumption of non-authorized local face mask products at a fairly high level in Indonesia also shows social acceptance of this behavior, leading people in the country to view the availability, purchase, and use of non-authorized local face masks as common practices with little or no connotation not profitable (Jirotmontree, 2013). The existence of favorable subjective norms can help consumers overcome negative perceptions about the quality of nonauthorized local face masks and may create a favorable bias in evaluating non-authorized local face masks because it will help them achieve cognitive consistency and avoid any cognitive dissonance.

Subjective norms are considered to affect consumer attitudes in purchasing controversial products (Xu et al., 2004). Similar to attitudes toward behavior, subjective norms are also affected by beliefs (Liu, Brock, Shi, Chu \& Tseng, 2013). Studies conducted by Kim and Chung (2011), Souiden \& Diagne (2009) and Sukato and Elsey (2009) show that taking face masks as skin care has supported a positive correlation between subjective normative concepts and behavioral intentions when purchasing skin care products. Therefore, consumers believe that people who are considered important also have favorable subjective norms about these behaviors. Subjective norms from friends and family members (Prendergast et al., 2002), as well as significant others (Penz and Stöttinger, 2005) have a significantly influence on the purchase intention of consumers' non-authorized local face masks.

\section{Ethical Judgements}

Ethical judgment is "an individual's personal evaluation of the extent to which some behavior or action is ethical or unethical" (Sparks and Pan 2009). In terms of business ethics literature, ethical judgment has become an important factor explaining consumer behavioral intentions (Chiu 2002; Hunt and Vitell 1986). The effect of ethical judgments on behavioral intention, especially in WOM, can be found both in the area of consumer commitment (Ingram et al. 2005), their online expertise (Román and Cuestas 2008) as well as purchase intentions (Wilcox et al., 2009). In fact, from a previous study, some non-authorized local face mask buyers considered purchasing this product to be beneficial and ethical (Chaudhry and Stumpf, 2011) 
Volume 3 Issue 9 (September 2021) PP. 67-90 DOI 10.35631/AIJBES.39006

and even improve people's welfare (Ang et al., 2001). It can be seen here that high nonauthorized proneness consumers purchasing non-authorized products will have more favorable ethical judgments about purchasing these non-authorized local face masks.

Ethical consumers might put forward some of these non-authorized local face mask product attributes to maintain cognitive consistency and avoid dissonance. In the context of nonauthorized local face mask products, consumers make favorable ethical judgments regarding purchases of non-authorized local face masks by better viewing and evaluating these nonauthorized local face masks because this will help them avoid cognitive dissonances that allow mismatches between their beliefs and action.

Consumers who have good morals regarding the purchase behavior of non-authorized local face masks are more likely to buy non-authorized local face mask products than those who have unfavorable moral beliefs (Wilcox et al., 2009). Consumers who consider this behavior ethically acceptable to buy non-authorized local face masks, more like to buy them.

\section{Product Evaluation}

Product evaluation is one of several stages in the purchasing decision process (Kotler et al., 2003). Product evaluation as an important predictor of purchase intention is an overall assessment of various economic, functional attributes, including price, quality, reliability and image (Dodds et al., 1991). According to Park and Lee (2013), the phase before making a purchase decision is product evaluation, so that there mutually satisfactory relationship. If customers have very positive ethical judgments or subjective norms of buying non-authorized local face masks, there will affect the product evaluation process of consumers in purchasing these non-authorized local face masks on the grounds of product quality, prices are quite affordable compared to authorized face mask products (Sharma and Chan, 2016).

\section{Purchase Intention}

Purchase intention refers to the stage of a respondent's propensity to act before making a purchase (Martinez and Kim, 2012). Purchase Intention can be defined as measuring the probability of consumers purchasing insured products. It states that the intent to purchase is directly proportional to the probability of purchase (Singh \& Sahni, 2019). According to Fishbein and Ajzen (1975), purchase intention can be used to forecast consumer consumption behavior, reflect subjective awareness, or predict customer purchase possibilities. Purchase intentions toward a product will lead to a purchase decision to help evaluate consumer selection for other products of interest (Lee \& Shin, 2010; Balakrishnan et al., 2014; Akhter, 2003; Bian $\&$ Forsythe, 2012). According to study Sharma and Chan (2016), consumers who purchase non-authorized local face masks have a very positive product evaluation in ethical decisions or subjective norms of non-authorized local face masks will have an significant influence on the level of purchasing intention, which in turn influences the non-authorized local face masks purchase decision.

\section{Purchase Decision}

Purchase decisions can be defined as before, during, and after the purchase of products or services, the customer makes decisions about which goods or services to buy in exchange for money in the market (Lumen, 2019) A consumer's purchase decision is the outcome of a series of decisions they make before making a purchase, which begins until consumers are able to fulfill a need (Hanaysha, 2018). The process by which consumers make purchasing decisions, use, and set purchased products and services, as well as factors that influence purchase Copyright (C) GLOBAL ACADEMIC EXCELLENCE (M) SDN BHD - All rights reserved 
Volume 3 Issue 9 (September 2021) PP. 67-90 DOI 10.35631/AIJBES.39006

decisions and product use, is known as consumer buying behavior (Lamb et al., 2010). According to Kotler and Keller (2012), the purchase decision process is divided into five stages: problem identification, information analysis, alternative evaluation, purchase decision, and post - purchase behavior. Purchase intention can influence purchase decisions and have been shown to have a positive relationship with buying behavior (Chan, 2001; Chan and Yam, 1995). Buying behavior includes buying attitudes and intentions because it refers to consumers' decisions about spending their resources on different products (Schiffman, Hansen and Kanuk, 2008). Buying behavior that encourages the selection, purchase, and consumption of goods and services for the satisfaction of consumer desires. When consumer behavior is under volitional influence, its output is a feature of its intentions (Ajzen, 1991). Besides, Sharma and Chan (2016) found that several factors such, proneness, subjective norms, ethical judgements, and product evaluation can influence purchase intention and purchase decision of non-authorized products. Therefore, the result of all factors that have been mentioned in this study (non-authorized proneness, subjective norms, ethical judgements, product evaluation \& purchase intention), are predicted to have significantly influence to purchase decision of nonauthorized local face masks.

\section{Conceptual Framework}

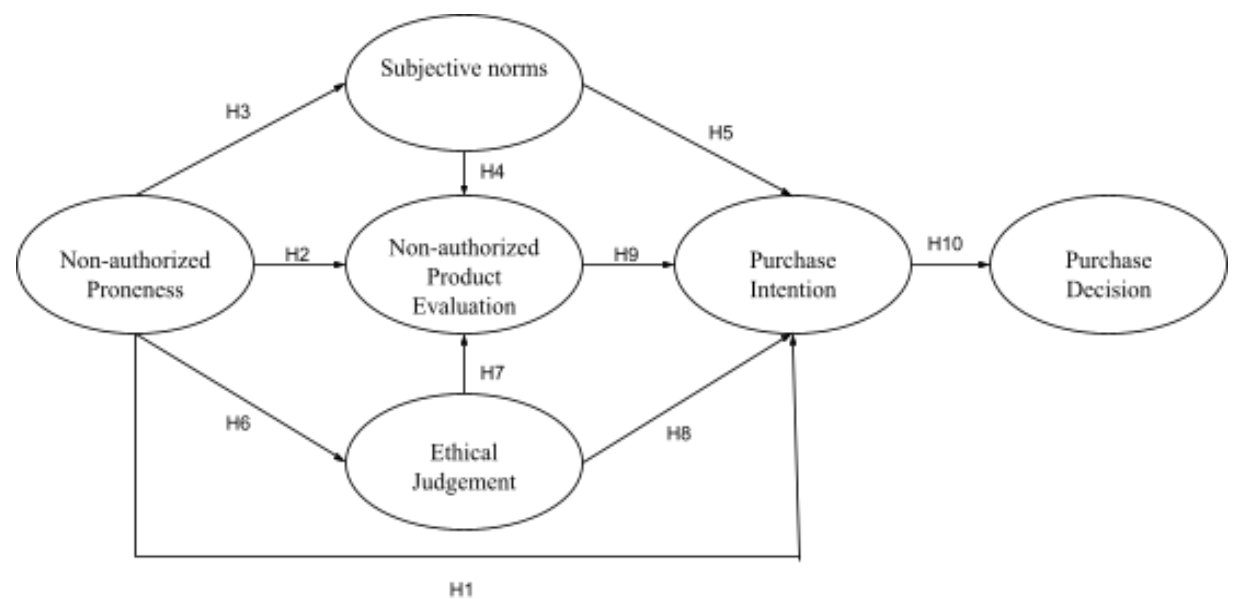

Figure 2: Conceptual Framework

The following hypothesis proposed for this study is as follows:

H1. Non-authorized proneness has a significantly influence on the purchase intention for a nonauthorized local face mask.

H2. Non-authorized proneness has a significantly influence on the evaluation of a nonauthorized local face mask product.

H3. Non-authorized proneness has a significantly influence on the subjective norms about buying a non-authorized local face masks product.

H4. Subjective norms can have a significantly influence on the evaluation of these nonauthorized local face masks.

H5. Subjective norms about buying non-authorized local face masks have a significantly influence on purchase intentions for the product.

H6. Non-authorized proneness has a significantly influence on ethical judgments about buying non-authorized local face masks. 
Volume 3 Issue 9 (September 2021) PP. 67-90 DOI 10.35631/AIJBES.39006

H7. The ethical judgements of purchasing non-authorized local face masks have a significantly influence on the evaluation of these products.

H8. Ethical judgements regarding buying non-authorized face mask products have a significantly influence on the purchase intention of these products.

H9. Evaluation of non-authorized local face mask products has a significantly influence on purchasing intention for the product.

H10. Purchase intention has a significantly influence on purchase decisions of non-authorized local face masks.

\section{Methodology}

\section{Study Sample and Data Collection}

In this study, mixed method research that combined qualitative and quantitative approach will be conducted by using semi structured interviews and surveys. This study will use qualitative semi-structured interviews and online questionnaires to gather the data. The researcher conduct semi-structure interview as preliminary research. The requirements for selecting participants in this study are those who have purchased non-authorized local face masks. This study found out the participants by approaching some of the author relations. Then, for this study will choose and recruit 4 participants through online chat before the semi-structured interview to make sure that the respondents are according to participants' criteria and willing to participate voluntarily during the entire semi-structured interviews.

The quantitative data for this study is collected through distribution of a questionnaire. The questionnaire targeted millennial and generation $\mathrm{z}$ females between 15-38 years old that have purchased non-authorized local face masks. The participants can provide information about their perception about the non-authorized local face masks that will provide insights into this study. The sample technique used in this study was judgmental sampling with minimum 200 samples. The online survey will be conducted to local participants who live in Indonesia.

\section{Data Analysis}

\section{Open Coding}

Open coding is a textual content analysis approach that involves labeling, specifying, and developing categories based on dimension and characteristics (Khandkar, 2019). Posing sensitizing questions and continuously comparing data and codes are key elements of open coding (Vollstedt \& Rezat, 2019). This study applied open coding, which includes labeling and categorizing the qualitative data.

\section{Descriptive Statistics}

For quantitative data use descriptive statistics. Descriptive statistics are a critical part for analyzing initial data and providing a basis for comparing variables with inferential statistical tests (Yellapu, 2018).

\section{Partial Least Square (PLS-SEM) Analysis}

For this study will process the collected data using the Partial Least Square (PLS) method. The PLS method will build a predictive model involving several highly collinear variables (Tobias, 1995).The researcher conduct validity and reliability test using SmartPLS, assessment of indicator reliability can be done by squaring each outer loadings to determine the reliability value of an indicator with the preferred minimum value of 0.7 (Wong , 2013) and for validity 
Volume 3 Issue 9 (September 2021) PP. 67-90 DOI 10.35631/AIJBES.39006

test the AVE must be at least 0.5 or higher (Malhotra, 2007). The collinearity test is carried out to examine potential collinearity problems, Variance Inflation Factor (VIF) must be 5 or lower to avoid collinearity problems. The researcher also used bootstrapping to test the hypothesis, using a two-tailed t-test of $5 \%$ of significance level in order for the path coefficient to be considered significant, the T-statistic must be greater than 1.96 . This study also test coefficient of Determination (R2) and Stone-Giesser test (Q2 ) to measure of the proportion of variance in which the dependent variable is above average later explained by the independent variable. The researcher also test $\mathrm{F}$ square effect size, to determine the significance of the observed association between differences or correlations. Total Indirect, total Effect, and mediation result will be tested to determine the independent variable on the dependent variable and mediation variable.

\section{Measures}

In this study, the existing scale will be used for operational variables of all constructs including non-authorized proneness (Sharma and Chan, 2011), subjective norms (Ajzen, 1991), ethical judgment (Kwong et al., 2009) and product evaluation and purchase intention (de Matos et al., 2007) on a non-authorized local face mask. All the scales use a seven-point Likert type format ranging from 1 strongly disagree to 7 strongly agree, except for purchase intentions 1 very unlikely to 7 very likely.

\section{Discussion and Analysis}

\section{Open Coding}

\section{Factor Influenced People To Buy Non-Authorized Local Face Masks}

From the interview, it can be concluded that the factor that influenced people to buy nonauthorized face masks is because of the low price, popularity, packaging, the product claims that match with skin needs, word of mouth and the positive reviews, especially from ordinary people. This category also will be evaluated further using a quantitative approach.

\section{Reasons To Buy Non-Authorized Local Face Masks}

In this interview, it can be concluded that most of them initially were not aware of this nonauthorized local face mask. Respondents thought that as long as there were no side effects on their faces, they were still considered safe.

\section{Perception About Non-Authorized Local Face Masks}

From the interview, it can be concluded that consumer perceptions of non-authorized local face masks have slightly changed. Most of them have started to see the importance of the BPOM permit to ensure the safety of the local face mask, although one respondent still thinks that the BPOM permit was not too important. 
Volume 3 Issue 9 (September 2021) PP. 67-90

\section{Descriptive Statistics}

\begin{tabular}{|c|c|c|c|c|c|c|}
\hline NO. & VARIABLES & LABELS & MEAN & STD DEV & MIN & MAX \\
\hline \multirow[t]{8}{*}{1} & Non-authorized Proneness & NAP1 & 3.196 & 1.469 & 1 & 7 \\
\hline & & NAP2 & 3.000 & 1.428 & 1 & 7 \\
\hline & & NAP3 & 4.724 & 1.737 & 1 & 7 \\
\hline & & NAP4 & 4.984 & 1.815 & 1 & 7 \\
\hline & & NAP5 & 4.072 & 1.847 & 1 & 7 \\
\hline & & NAP6 & 4.408 & 1.838 & 1 & 7 \\
\hline & & NAP7 & 4.268 & 1.858 & 1 & 7 \\
\hline & & NAP8 & 5.052 & 1.671 & 1 & 7 \\
\hline \multirow[t]{3}{*}{2} & Subjective Norms & SN1 & 4.368 & 1.751 & 1 & 7 \\
\hline & & $\mathrm{SN} 2$ & 3.196 & 1.614 & 1 & 7 \\
\hline & & SN3 & 2.888 & 1.487 & 1 & 7 \\
\hline \multirow[t]{4}{*}{3} & Ethical Judgements & EJ1 & 3.868 & 1.765 & 1 & 7 \\
\hline & & $\mathrm{EJ} 2$ & 4.040 & 1.757 & 1 & 7 \\
\hline & & $\mathrm{EJ} 3$ & 4.572 & 1.86 & 1 & 7 \\
\hline & & EJ4 & 4.812 & 1.876 & 1 & 7 \\
\hline \multirow[t]{3}{*}{4} & Product Evaluation & PE1 & 3.956 & 1.707 & 1 & 7 \\
\hline & & PE2 & 3.876 & 1.726 & 1 & 7 \\
\hline & & PE3 & 3.488 & 1.659 & 1 & 7 \\
\hline \multirow[t]{3}{*}{5} & Purchase Intention & PI1 & 4.004 & 1.785 & 1 & 7 \\
\hline & & PI2 & 3.248 & 1.652 & 1 & 7 \\
\hline & & PI3 & 2.896 & 1.682 & 1 & 7 \\
\hline \multirow[t]{4}{*}{6} & Purchase Decision & PD1 & 3.016 & 1.565 & 1 & 7 \\
\hline & & PD2 & 4.596 & 1.831 & 1 & 7 \\
\hline & & PD3 & 4.956 & 1.667 & 1 & 7 \\
\hline & & PD4 & 4.424 & 1.701 & 1 & 7 \\
\hline
\end{tabular}

Partial Least Square (PLS-SEM) Analysis Result

Outer Model

Table 2: Composite Reliability

\begin{tabular}{lcl}
\hline \multicolumn{1}{c}{ Variable } & Composite Reliability & Reliability \\
Non-authorized Proneness & 0.878 & Reliable \\
Subjective Norms & 0.851 & Reliable \\
Ethical Judgements & 0.927 & Reliable \\
Product Evaluation & 0.910 & Reliable \\
Purchase Intention & 0.917 & Reliable \\
Purchase Decision & 0.844 & Reliable \\
\hline
\end{tabular}

All of the numbers are higher than 0.7. As a result, it is possible to conclude that all variables are reliable. 
Volume 3 Issue 9 (September 2021) PP. 67-90

Table 3: Convergent Validity

DOI 10.35631/AIJBES.39006

\begin{tabular}{lcc}
\hline \multicolumn{1}{c}{ Variable } & $\begin{array}{c}\text { Average Variance } \\
\text { Extracted (AVE) }\end{array}$ & Validity \\
Non-authorized & 0.508 & Valid \\
Proneness & 0.657 & Valid \\
Subjective Norms & 0.760 & Valid \\
Ethical Judgements & 0.771 & Valid \\
Product Evaluation & 0.786 & Valid \\
Purchase Intention & 0.576 & Valid \\
Purchase Decision & & \\
\hline
\end{tabular}

All of the variables' AVE values exceed 0.5, according to the current AVE calculation result. It indicates that all variables have been determined to be valid.

Table 4: Outer VIF Value

\begin{tabular}{cc}
\hline EJ1 & VIF \\
EJ2 & 2.562 \\
EJ3 & 3.582 \\
EJ4 & 2.386 \\
NAP1 & 2.602 \\
NAP2 & 2.016 \\
NAP3 & 2.068 \\
NAP5 & 1.742 \\
NAP6 & 1.428 \\
NAP7 & 1.628 \\
NAP8 & 1.477 \\
PD1 & 1.746 \\
PD2 & 1.505 \\
PD3 & 1.320 \\
PD4 & 1.622 \\
PE1 & 1.720 \\
PE2 & 2.749 \\
PE3 & 3.137 \\
PI1 & 1.645 \\
PI2 & 2.191 \\
PI3 & 2.464 \\
SN1 & 2.097 \\
SN2 & 1.380 \\
SN3 & 2.095 \\
\end{tabular}

All VIF values of all indicators passed the desired criteria based on the calculated VIF values. As a result, there is no indication of multicollinearity among the independent variables. 


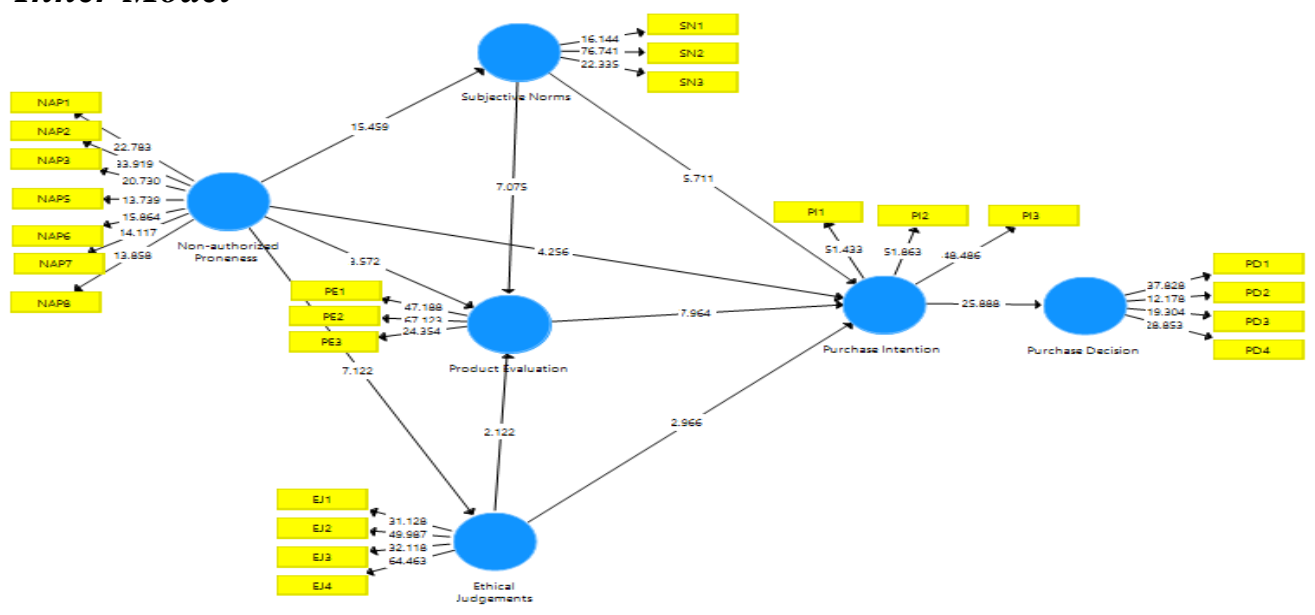

Figure 3: Bootstrapping Result

Table 5: Coefficient of Determination and Stone-Geisser






\section{Evaluation $\quad->$}

Purchase

Intention

Subjective Norms

$\begin{array}{lll}0.305 & 0.303 & 0.053\end{array}$

5.711

$\rightarrow \quad$ Purchase

Intention

Purchase

0.750

0.754

0.029

25.888

0.562

0.299

Intention $\quad \rightarrow$

Purchase Decision

The $\mathrm{R} 2$ of product evaluation is 0.413 , meaning that three latent variables (ethical judgements, non-authorized proneness, subjective norms) explain the $41.3 \%$ of the variance in product evaluation. The R2 of ethical judgements is 0.136 , meaning that one latent variable (nonauthorized proneness) explains the $13.6 \%$ of variance in ethical judgements. Then, R2 of subjective norms is 0.387 , which means that one latent variable (non-authorized proneness) explains the $38.7 \%$ of variance in subjective norms. Next, R2 score of purchase intention is 0.680 , meaning that four latent variables (ethical judgements, non-authorized proneness, product evaluation, subjective norms) explain the $68 \%$ of variance in purchase intention. Lastly, the R2 of purchase decision is 0.562, meaning that one latent variable (purchase intention) explains $56.2 \%$ of variance in purchase decision.

To determine the predictive relevance, this study used the Stone-Geisser test (Q2). The purpose of the test is to show the level to which the predictions are preferred. The blindfolding procedure in Smart-PLS would be used to generate the Q2 result. Based on Table 4.9, the Q2 result of product evaluation is 0.310 , ethical judgements is 0.098 , subjective norms is 0.251 , purchase intention is 0.527 , and lastly purchase decision is 0.299 .

\section{f square Effect Size}

Table 6: f2 Effect Size Result

$\begin{array}{cccccc}\text { Ethical } & \text { Non- } & \text { Product } & \text { Purchase } & \text { Purchase } & \text { Subjective } \\ \text { Judgements } & \text { authorized } & \text { Evaluation } & \text { Decision } & \text { Intention } & \text { Norms } \\ & \text { Proneness } & & & & \end{array}$

Ethical

0.023

0.040

Judgements

Non-authorized

0.157

0.050

0.084

0.631

Proneness

Product Evaluation

0.249

Purchase Decision

Purchase Intention

1.285

Subjective Norms

0.172

0.146

According to Chin L (1996), this study should examine the impact size between variables in addition to determining the variables significance in the model. A value of $\mathrm{f} 2$ of 0.35 indicates a high effect size, 0.15 indicates a medium effect size, and 0.02 indicates a small effect size (Wong 2013). 
Table 7: Total Effect Result

\begin{tabular}{lc}
\hline & $\begin{array}{c}\text { Purchase } \\
\text { Decision }\end{array}$ \\
Ethical Judgements -> Purchase Decision & -0.130 \\
Non-authorized Proneness -> Purchase Decision & 0.488 \\
Product Evaluation -> Purchase Decision & 0.277 \\
Purchase Intention -> Purchase Decision & 0.750 \\
Subjective Norms -> Purchase Decision & 0.343 \\
\hline
\end{tabular}

Another test, total indirect and total effect, was used to determine the statistical relevance and significance of the path coefficients. It is used in research to obtain different patterns of understanding of the effect of one variable on another. The result of total effect evaluates the percentage of influence caused by independent and mediating variables on dependent variables.

\section{Hypothesis Test}

Table 8: Hypothesis Test Result

\begin{tabular}{|c|c|c|c|c|}
\hline $\begin{array}{l}\text { Hypothe } \\
\text { sis }\end{array}$ & Structural Path & T Values & $\begin{array}{c}\mathbf{P} \\
\text { Values }\end{array}$ & Result \\
\hline $\mathrm{H} 1$ & $\begin{array}{l}\text { Non-authorized Proneness -> Purchase } \\
\text { Intention }\end{array}$ & 4.256 & 0.000 & Accepted \\
\hline $\mathrm{H} 2$ & $\begin{array}{l}\text { Non-authorized Proneness -> Product } \\
\text { Evaluation }\end{array}$ & 3.572 & 0.000 & Accepted \\
\hline H3 & $\begin{array}{l}\text { Non-authorized Proneness -> Subjective } \\
\text { Norms }\end{array}$ & 15.459 & 0.000 & Accepted \\
\hline $\mathrm{H} 4$ & Subjective Norms -> Product Evaluation & 7.075 & 0.000 & Accepted \\
\hline $\mathrm{H} 5$ & Subjective Norms -> Purchase Intention & 5.711 & 0.000 & Accepted \\
\hline H6 & $\begin{array}{l}\text { Non-authorized Proneness -> Ethical } \\
\text { Judgements }\end{array}$ & 7.122 & 0.000 & Accepted \\
\hline $\mathrm{H} 7$ & Ethical Judgements -> Product Evaluation & 2.122 & 0.034 & Accepted \\
\hline H8 & Ethical Judgements -> Purchase Intention & 2.966 & 0.003 & Accepted \\
\hline H9 & Product Evaluation -> Purchase Intention & 7.964 & 0.000 & Accepted \\
\hline $\mathrm{H} 10$ & Purchase Intention -> Purchase Decision & 25.888 & 0.000 & Accepted \\
\hline
\end{tabular}

a. H1. Non-authorized proneness has a significantly influence on the purchase intention for a non-authorized local face mask.

The hypothesis is accepted since the t-value is 4.256 greater than 1.96 at a significance level of $0.05(5 \%)$. That indicates that there is a significantly influence between nonauthorized proneness and purchase intention for a non-authorized local face mask.

b. H2. Non-authorized proneness has a significantly influence on the evaluation of a nonauthorized local face mask product.

The hypothesis is accepted since the t-value is 3.572 greater than 1.96 at a significance level of $0.05(5 \%)$. That indicates that non-authorized proneness has a significantly influence on the evaluation of a non-authorized local face mask product.

c. H3. Non-authorized proneness has a significantly influence on the subjective norms about buying a non-authorized local face masks product. 
Volume 3 Issue 9 (September 2021) PP. 67-90 DOI 10.35631/AIJBES.39006

The hypothesis is accepted since the t-value is 15.459 greater than 1.96 at a significance level of $0.05(5 \%)$. That indicates that non-authorized proneness has a significantly influence on the subjective norms about buying a non-authorized local face masks product.

d. H4. Subjective norms can have a significantly influence on the evaluation of these nonauthorized local face masks.

The hypothesis is accepted since the t-value is 7.075 greater than 1.96 at a significance level of $0.05(5 \%)$. That indicates that subjective norms can have a significantly influence on the evaluation of these non-authorized local face masks.

e. H5. Subjective norms about buying non-authorized local face masks have a significantly influence on purchase intentions for the product.

The hypothesis is accepted since the t-value is 5.711 greater than 1.96 at a significance level of $0.05(5 \%)$. That indicates that subjective norms about buying non-authorized local face masks have a significantly influence on purchase intentions for the product.

f. H6. Non-authorized proneness has a significantly influence on ethical judgments about buying non-authorized local face masks.

The hypothesis is accepted since the t-value is 7.122 greater than 1.96 at a significance level of $0.05(5 \%)$. That indicates that non-authorized proneness has a significantly influence on ethical judgments about buying non-authorized local face masks.

g. H7. The ethical judgements of purchasing non-authorized local face masks have a significantly influence on the evaluation of these products.

The hypothesis is accepted since the t-value is 2.122 greater than 1.96 at a significance level of $0.05(5 \%)$. That indicates that ethical judgements of purchasing non-authorized local face masks have a significantly influence on the evaluation of these products.

h. H8. Ethical judgements regarding buying non-authorized face mask products have a significantly influence on the purchase intention of these products.

The hypothesis is accepted since the t-value is 2.966 greater than 1.96 at a significance level of $0.05(5 \%)$. That indicates that ethical judgements regarding buying non-authorized face mask products have a significantly influence on the purchase intention of these products.

i. H9. Evaluation of non-authorized local face mask products has a significantly influence on purchasing intention for the product.

The hypothesis is accepted since the t-value is 7.964 greater than 1.96 at a significance level of $0.05(5 \%)$. That indicates that evaluation of non-authorized local face mask products has a significantly influence on purchasing intention for the product.

j. H10. Purchase intention has a significantly influence on purchase decisions of nonauthorized local face masks.

The hypothesis is accepted since the t-value is 25.888 greater than 1.96 at a significance level of $0.05(5 \%)$. That indicates that purchase intention has a significantly influence on purchase decisions of non-authorized local face masks.

\section{Conclusions}

This research concluded that consumer awareness of the safety of non-authorized local face masks is still relatively low. The importance of the BPOM permission in ensuring the safety of the non-authorized local face mask has been ignored by consumers. There are still many consumers who are still interested in buying non-authorized local face masks which can also be seen from the sales of non-authorized local face masks which are still quite high in the market. The importance of the BPOM permission in ensuring the safety of the non-authorized local face mask has been ignored by consumers. Consumers still think that non-authorized local face masks are good as long as there were no side effects on their faces. 
Based on the result of the interview and PLS analysis, it can be concluded there are significant relationships between non-authorized proneness, subjective norms, ethical judgments, and product evaluation toward purchase decision that influence consumer buying behavior for nonauthorized local face masks. This study explains these mixed findings by showing that the nonauthorized local face mask users are not only more non-authorized proneness but they also have more favorable subjective norms, ethical judgments, product evaluation that direct to buying behavior of non-authorized local face mask.

\section{References}

Abid, M. \& Rehman, M.A. 2016, "ANTECEDENTS OF CONSUMERS' BUYING BEHAVIOR TOWARDS COUNTERFEIT PRODUCTS: AN EMPIRICAL STUDY", Aktual'ni Problemy Ekonomiky = Actual Problems in Economics, , no. 176, pp. 89-99.

Ajzen, I., T.. Barnett, K. B., T.. Barnett, D. S. C., Barton, L., Boatright, J. R., Bond, M., ... Vinten, G. (1991, January 1). Ethical Judgment and Whistleblowing Intention: Examining the Moderating Role of Locus of Control. Journal of Business Ethics. https://link.springer.com/article/10.1023/A:1022911215204.

Ajzen, I. (1991). The theory of planned behavior. Organizational Behavior and Human Decision Processes, 50(2), 179-211. https://doi.org/10.1016/0749-5978(91)90020-t

Albers-Miller, N. D. (1999). Consumer misbehavior: why people buy illicit goods. Journal of Consumer Marketing, 16(3), 273-287. https://doi.org/10.1108/07363769910271504

Ang, S. H., Cheng, P. S., Lim, E. A., \&amp; Tambyah, S. K. (2001). Spot the difference: consumer responses towards counterfeits. Journal of Consumer Marketing, 18(3), 219235. https://doi.org/10.1108/07363760110392967

Balakrishnan, B. K., Dahnil, M. I., \&amp; Yi, W. J. (2014). The Impact of Social Media Marketing Medium toward Purchase Intention and Brand Loyalty among Generation Y. Procedia - Social and Behavioral Sciences, 148, 177-185. https://doi.org/10.1016/j.sbspro.2014.07.032

Barhemmati, N., \&amp; Ahmad, A. (2015). Effects of Social Network Marketing (SNM) on Consumer Purchase Behavior through Customer Engagement. Journal of Advanced Management Science, 307-311. https://doi.org/10.12720/joams.3.4.307-311

Baron, R. M., \& Kenny, D. A. (1986). The Moderator-Mediator Variable Distinction in Social Psychological Research. Conceptual, Strategic, and Statistical Considerations. Journal of Personality and Social Psychology, 51(6), 1173-1182. https://doi.org/10.1037/00223514.51.6.1173

Baumann, L. (2008). Understanding and Treating Various Skin Types: The Baumann Skin Type Indicator. Dermatologic Clinics, 26(3), 359-373. https://doi.org/10.1016/j.det.2008.03.007

Bian, Q., \&amp; Forsythe, S. (2012). Purchase intention for luxury brands: A cross cultural comparison. Journal of Business Research, 65(10), 1443-1451. https://doi.org/10.1016/j.jbusres.2011.10.010

Bian, X., \&amp; Moutinho, L. (2011). Counterfeits and branded products: effects of counterfeit ownership. Journal of Product \&amp; Brand Management, 20(5), 379-393. https://doi.org/10.1108/10610421111157900

Boon, L. K., Fern, Y. S., \& Chee, L. H. (2020). Generation Y's Purchase Intention towards Natural Skincare Products: A PLS-SEM Analysis. Global Business and Management Research, 12(1), 61-77. https://www.proquest.com/scholarly-journals/generation-yspurchase-intention-towards-natural/docview/2436884468/se-2?accountid=31562 
Volume 3 Issue 9 (September 2021) PP. 67-90 DOI 10.35631/AIJBES.39006

Budiman, S., \&amp; Wijaya, T. (2014). Purchase Intention of Counterfeit Products: The Role of Subjective Norm. International Journal of Marketing Studies, 6(2). https://doi.org/10.5539/ijms.v6n2p145

Carter, L. L., \& Maher, A. A. (2015). Consumer Perceptions of Foreign Goods: Modeling the Path from Evaluation to Purchase. Journal of Marketing Development and Competitiveness, 9(1), 32-49. https://brama.sgh.waw.pl/business/docview/1727386922/fulltextPDF/4D5E3BF90FB 344A4PQ/,DanaInfo=search.proquest.com,SSL+42?accountid=45618

Chan, R. Y. K. (2001). Determinants of Chinese consumers' green purchase behavior. Psychology and Marketing, 18(4), 389-413. https://doi.org/10.1002/mar.1013

Chan, R. Y.-K., \&amp; Yam, E. (1995). Green movement in a newly industrializing area: A survey on the attitudes and behaviour of the Hong Kong citizens. Journal of Community \&amp; Applied Social Psychology, 5(4), 273-284. https://doi.org/10.1002/casp.2450050405

Chaudhary, R. (2018). Green buying behavior in India: an empirical analysis. Journal of Global Responsibility, 9(2), 179-192. https://doi.org/10.1108/jgr-12-2017-0058

Chaudhry, P. E., \&amp; Stumpf, S. A. (2011). Consumer complicity with counterfeit products. Journal of Consumer Marketing, 28(2), 139-151. https://doi.org/10.1108/07363761111115980

Chin, J., Jiang, B., Mufidah, I., Persada, S., \&amp; Noer, B. (2018). The Investigation of Consumers' Behavior Intention in Using Green Skincare Products: A ProEnvironmental Behavior Model Approach. Sustainability, 10(11), 3922. https://doi.org/10.3390/su10113922

Chiu, R. K. (2002). Ethical judgement, locus of control, and whistleblowing intention: a case study of mainland Chinese MBA students. Managerial Auditing Journal, 17(9), 581587. https://doi.org/10.1108/02686900210447588

Clifford, N. J., Cope, M., Gillespie, T. W., \&amp; French, S. (2016). Key methods in geography. SAGE.

Corbin, J., \&amp; Strauss, A. (2008). Basics of Qualitative Research (3rd ed.): Techniques and Procedures for Developing Grounded Theory. https://doi.org/10.4135/9781452230153

Creswell, John, 1994, Research Design: Qualitative and Quantitative Approaches, London: SAGE Publications

Creswell, J. W. (2002). Educational Research: Planning, Conducting, and Evaluating Quantitative and Qualitative Research.

Dapas, C. C., Sitorus, T., Purwanto, E., \& Ihalauw, J. J. O. I. (2019). The effect of service quality and website quality of zalora.Com on purchase decision as mediated by purchase intention. Quality - Access to Success, 20(169), 87-92.

Desai, K. (2014). A study on consumer buying behaviour of cosmetic products in kolhapur. Reviews of Literature, 1(10). 1-11.

Do Consumers' Ethical Judgments Matter for Purchase Intentions in Online Gray Markets? (2019). Journal of Marketing Development and Competitiveness, 13(4). https://doi.org/10.33423/jmdc.v13i4.2350

Dodds, W. B., Monroe, K. B., \&amp; Grewal, D. (1991). Effects of Price, Brand, and Store Information on Buyers' Product Evaluations. Journal of Marketing Research, 28(3), 307. https://doi.org/10.2307/3172866

Edwin, Kubai. (2019). Reliability and Validity of Research Instruments Correspondence to kubaiedwin@yahoo.com.

https://www.researchgate.net/publication/335827941_Reliability_and_Validity_of_Re searc

Copyright (C) GLOBAL ACADEMIC EXCELLENCE (M) SDN BHD - All rights reserved 
Volume 3 Issue 9 (September 2021) PP. 67-90 DOI 10.35631/AIJBES.39006

Febriyana ramadhani, y. E. N. I. (2017). Pengaruh inovasi produk dan harga terhadap niat beli masker mustika ratu (studi pada pengunjung giant hypermarket di surabaya). Jurnal ilmu manajemen (jim), 5(4).

Fishbein, M., \&amp; Ajzen, I. (1975). Belief, Attitude, Intention and Behavior: an Introduction to Theory and Research. Addison-Wesley.

Formats*: (n.d.). Indonesia Skin Care Products Market Size, Share \&amp; Forecast by 2027. Allied Market Research. https://www.alliedmarketresearch.com/indonesia-skin-careproducts-market-A06724.

Gabriel, J. (2008). The green beauty guide: your essential resource to organic and natural skin care, hair care, makeup, and fragrances. Health Communications.

Garrett, T. C., Lee, S., \&amp; Chu, K. (2017). A store brand's country-of-origin or store image: what matters to consumers? International Marketing Review, 34(2), 272-292. https://doi.org/10.1108/imr-03-2015-0083

Garson, G. D., \&amp; Cooper, J. A. (2015). Multivariate statistics and qualitative methodology. Statistical Associates Publishers.

Greenwood, D. (2020, August 21). Are At-Home Face Masks Vital For Peace Of Mind Now? British Vogue. https://www.vogue.co.uk/beauty/article/face-masks-vital-selfcare.

Ha, S., \&amp; Lennon, S. J. (2006). Purchase Intent for Fashion Counterfeit Products: Ethical Ideologies, Ethical Judgments, and Perceived Risks. Clothing and Textiles Research Journal, 24(4), 297-315. https://doi.org/10.1177/0887302x06293068

Hair Jr, J. F., Black, W. C., Babin, B. J., \& Anderson, R. E. (2014). Multivariate Data Analysis (Seventh). https://doi.org/10.1002/9781118895238.ch8

Hanaysha, J. R. (2018). An examination of the factors affecting consumer's purchase decision in the Malaysian retail market. PSU Research Review, 2(1), 7-23. https://doi.org/10.1108/prr-08-2017-0034

Hart, C. (2018). Doing a Literature Review: Releasing the Research Imagination. Journal of Perioperative Practice.

Hayes, A. F. (2009). Beyond Baron and Kenny: Statistical Mediation Analysis in the New Millennium. Communication Monographs, 76(4), 408-420. https://doi.org/10.1080/03637750903310360

Hirschmann, R. (2020, May 26). Indonesia: preferred skincare product functions by age group 2019. Statista. https://www.statista.com/statistics/1113468/indonesia-preferredskincare-product-functions-by-age-group/.

Hunt, S. D., \&amp; Vitell, S. (1986). A General Theory of Marketing Ethics. Journal of Macromarketing, 6(1), 5-16. https://doi.org/10.1177/027614678600600103

Ingram, K., Lewis-Palmer, T., \&amp; Sugai, G. (2005). Function-Based Intervention Planning. Journal of Positive Behavior Interventions, 7(4), 224-236. https://doi.org/10.1177/10983007050070040401

Ingram, K., Lewis-Palmer, T., \&amp; Sugai, G. (2005). Function-Based Intervention Planning. Journal of Positive Behavior Interventions, 7(4), 224-236. https://doi.org/10.1177/10983007050070040401

Investorid. (n.d.). Industri Kosmetik Nasional Tumbuh 20\%. investor.id. https://investor.id/archive/industri-kosmetik-nasional-tumbuh-20.

Julie Ponto, Phd, Aprn, Agcns-Bc, Aocns®. (2015). Understanding and Evaluating Survey Research. Journal of the Advanced Practitioner in Oncology, 6(2). https://doi.org/10.6004/jadpro.2015.6.2.9

Kemenperin: Perubahan Gaya Hidup Dorong Industri Kosmetik. Kementerian Perindustrian. (n.d.). https://kemenperin.go.id/artikel/21460/Perubahan-Gaya-Hidup-DorongIndustri-Kosmetik. 
Volume 3 Issue 9 (September 2021) PP. 67-90 DOI 10.35631/AIJBES.39006

Khandkar, S. H. (2009). Open coding. University of Calgary, 23, 2009.

Kim, H. Y., \&amp; Chung, J. E. (2011). Consumer purchase intention for organic personal care products. Journal of Consumer Marketing, 28(1), 40-47. https://doi.org/10.1108/07363761111101930

Klarmann, C., Wiedmann, K.-P., \&amp; Hennigs, N. (2012). Luxury Longing and Counterfeit Complicity: A Consumer Typology based on the Perception of Luxury Value and Counterfeit Risk. Luxury Marketing, 261-277. https://doi.org/10.1007/978-3-83494399-6_15

Kompasiana.com. (2020, June 4). Kecantikan Menjadi Gaya Hidup Sehingga Mendorong Industri Kosmetik di Indonesia. KOMPASIANA. https://www.kompasiana.com/syahansyah8187/5ed91b2d097f3670976c7173/kecantik an-menjadi-gaya-hidup-sehingga-mendorong-industri-kosmetik-di-indonesia?page $=2$.

Konstantopoulou, A., Rizomyliotis, I., Konstantoulaki, K., \&amp; Badahdah, R. (2019). Improving SMEs' competitiveness with the use of Instagram influencer advertising and eWOM. International Journal of Organizational Analysis, 27(2), 308-321. https://doi.org/10.1108/ijoa-04-2018-1406

Koran.tempo.co. (2020, January 26). Perubahan Gaya Hidup Dorong Industri Kosmetik Ekonomi dan Bisnis. Tempo. https://koran.tempo.co/read/ekonomi-danbisnis/449594/perubahan-gaya-hidup-dorong-industri-kosmetik?utm_.

Kotler, P., Ang, S.H., Leong, S.M., Tan, T.C. (2003), Marketing Management: An Asian Perspective. Singapore: Pearson Education Asia

Kotler, P., \& Keller, K. L. (2012). Marketing management (14th Ed.). New Jersey: PrenticeHall, Englewood Cliffs.

Lamb., Charles, W., Hair, J. F., McDaniel, C. (2010). Marketing. Jakarta: Salemba Empat

Lawther, Steven \& Hastings, Gerard \& Lowry, R.. (1997). De-marketing: Putting Kotler and Levy's ideas into practice. Journal of Marketing Management. 13. 315-325. 10.1080/0267257X.1997.9964475.

Lee, K.-H., \&amp; Shin, D. (2010). Consumers' responses to CSR activities: The linkage between increased awareness and purchase intention. Public Relations Review, 36(2), 193-195. https://doi.org/10.1016/j.pubrev.2009.10.014

Liu, M. T., Brock, J. L., Shi, G. C., Chu, R., \&amp; Tseng, T. H. (2013). Perceived benefits, perceived risk, and trust. Asia Pacific Journal of Marketing and Logistics, 25(2), 225248. https://doi.org/10.1108/13555851311314031

Lumen. (n.d.). The Consumer Decision Process. Lumen boundless marketing.Retrieved from https://courses.lumen learning.com/boundless-marketing/chapter/the-consumerdecision-process/ (2019, Sept 15).

Martinez, B., \&amp; Kim, S. (2012). Predicting purchase intention for private sale sites. Journal of Fashion Marketing and Management: An International Journal, 16(3), 342365. https://doi.org/10.1108/13612021211246080

Market Research Company offers Syndicate \&amp; Custom Market Research Reports with Consulting Services - Allied Market Research. (n.d.). https://www.alliedmarketresearch.com/sheet-face-mask-market-A05993\.

Matos, C. A. D., Ituassu, C. T., \&amp; Rossi, C. A. V. (2007). Consumer attitudes toward counterfeits: a review and extension. Journal of Consumer Marketing, 24(1), 36-47. https://doi.org/10.1108/07363760710720975

Matos, C. A. D., Ituassu, C. T., \&amp; Rossi, C. A. V. (2007). Consumer attitudes toward counterfeits: a review and extension. Journal of Consumer Marketing, 24(1), 36-47. https://doi.org/10.1108/07363760710720975 
Volume 3 Issue 9 (September 2021) PP. 67-90 DOI 10.35631/AIJBES.39006

Malhotra, N. K., Nunan, D., \& Birks, D. F. (2016). Marketing research. In The Marketing Book: Seventh Edition. https://doi.org/10.4324/9781315890005

Martinez, L.F. \& Jaeger, D.S. 2016, "Ethical decision making in counterfeit purchase situations: the influence of moral awareness and moral emotions on moral judgment and purchase intentions", The Journal of Consumer Marketing, vol. 33, no. 3, pp. 213223.

Mcintosh, M. J., \&amp; Morse, J. M. (2015). Situating and Constructing Diversity in SemiStructured Interviews. Global Qualitative Nursing Research, 2, 233339361559767. https://doi.org/10.1177/2333393615597674

Megel, M. E., \& Heermann, J. A. (1994). Methods of data collection. Plastic Surgical Nursing, 14(2), 109-110. https://doi.org/10.1097/00006527-199406000-00014

Michaelidou, N., \&amp; Christodoulides, G. (2011). Antecedents of attitude and intention towards counterfeit symbolic and experiential products. Journal of Marketing Management, 27(9-10), 976-991. https://doi.org/10.1080/0267257x.2010.549189

Michaelidou, N., \&amp; Christodoulides, G. (2011). Antecedents of attitude and intention towards counterfeit symbolic and experiential products. Journal of Marketing Management, 27(9-10), 976-991. https://doi.org/10.1080/0267257x.2010.549189

Morganti, P., Yudin, V., Morganti, G., \&amp; Coltelli, M.-B. (2020). Trends in Surgical and Beauty Masks for a Cleaner Environment. Cosmetics, 7(3), 68. https://doi.org/10.3390/cosmetics7030068

Mohamad Yunus, ain, Mat Som, R., Abdul Majid, A., Munirah Ungku Abdul Aziz, U., \& Khalid Mohd Abas, M. (2018). Generation Y Purchase Intention of Personal Care Products: The Influence of Attitude, Subjective Norms and Perceived Behavioural Control. Journal of International Business, Economics and Entrepreneurship, 3(2), $2550-1429$.

N., Ramya \& Ali, Dr. (2016). Factors affecting consumer buying behavior.

Nazatul Shima, A.R. \& K Sarojani, D.K. 2018, "Factors that influence Malay students in purchasing skincare products in Malaysia", Journal of Business and Retail Management Research, vol. 13, no. 1.

Nawawi, M. T. (2016). Factors of Consumer Behavior That Affect Purchasing Decisions on Blackberry Smartphone. The Winners, 17(1), 59. https://doi.org/10.21512/tw.v17i1.1810

Nia, A., \&amp; Zaichkowsky, J. L. (2000). Do counterfeits devalue the ownership of luxury brands? Journal of Product \&amp; Brand Management, 9(7), 485-497. https://doi.org/10.1108/10610420010351402

Nilforoushzadeh, M. A., Amirkhani, M. A., Zarrintaj, P., Moghaddam, A. S., Mehrabi, T., Alavi, S., \&amp; Sisakht, M. M. (2018). Skin care and rejuvenation by cosmeceutical facial mask. Journal of Cosmetic Dermatology, 17(5), 693-702. https://doi.org/10.1111/jocd.12730

Noor, N. M., Muhamad, N. J., Sahabudin, N. A., \&amp; Mustafa, Z. (2018). Development of Skin Care Routine Support System. Advanced Science Letters, 24(10), 7830-7833. https://doi.org/10.1166/asl.2018.13026

Nugroho, R. S. (2021, January 31). 4 Merek Masker Organik Ini Ilegal, Belum Kantongi Izin BPOM, Apa Saja? Halaman all. KOMPAS.com. https://www.kompas.com/tren/read/2021/01/31/194500265/4-merek-masker-organikini-ilegal-belum-kantongi-izin-bpom-apa-saja?page=all.

P, M., G, M., Hd, C., \&amp; A, G. (2019). Beauty Mask: Market and Environment. Journal of Clinical and Cosmetic Dermatology, 3(2). https://doi.org/10.16966/2576-2826.141 
Volume 3 Issue 9 (September 2021) PP. 67-90 DOI 10.35631/AIJBES.39006

Palmer, C., \& Bolderston, A. (2006). A Brief Introduction to Qualitative Research. Canadian Journal of Medical Radiation Technology, 37(1), 16-19. https://doi.org/10.1016/s08205930(09)60112-2

Park, S.-Y., \&amp; Lee, S. W. (2013). Effects of a perceived brand crisis on product evaluation and purchase intention: the moderating roles of brand credibility and brand attachment. Journal of Global Scholars of Marketing Science, 23(2), 213-226. https://doi.org/10.1080/21639159.2013.763488

Partridge, H., Edwards, S. L., \&amp; Thorpe, C. (2010). Evidence-based practice: Information professionals' experience of information literacy in the workplace. Practising Information Literacy, 273-297. https://doi.org/10.1016/b978-1-876938-79-6.50013-3

Phau, I., Teah, M., \&amp; Lwin, M. (2013). PiratingPirates of the Caribbean: The curse of cyberspace. Journal of Marketing Management, 30(3-4), 312-333. https://doi.org/10.1080/0267257x.2013.811280

Phau, I., Teah, M., \&amp; Lwin, M. (2013). PiratingPirates of the Caribbean: The curse of cyberspace. Journal of Marketing Management, 30(3-4), 312-333. https://doi.org/10.1080/0267257x.2013.811280

Preacher, K. J., Rucker, D. D., \&amp; Hayes, A. F. (2007). Addressing Moderated Mediation Hypotheses: Theory, Methods, and Prescriptions. Multivariate Behavioral Research, 42(1), 185-227. https://doi.org/10.1080/00273170701341316

Prendergast, G., Chuen, L. H., \&amp; Phau, I. (2002). Understanding consumer demand for non-deceptive pirated brands. Marketing Intelligence \&amp; Planning, 20(7), 405416. https://doi.org/10.1108/02634500210450846

Putri, N. D. (n.d.). Fakto-faktor Keputusan Konsumen Dalam Membeli Kosmetika Perawatan Wajah. JTR-Jurnal Tata Rias. http://journal.unj.ac.id/unj/index.php/jtr/article/view/13219.

Qazzafi, Sheikh. (2020). Factor Affecting Consumer Buying Behavior: A Conceptual Study. 2321-0613.

https://www.researchgate.net/publication/341407314_Factor_Affecting_Consumer_B uying_Behavior_A_Conceptual_Study

Quoquab, Farzana \& Pahlevan, Sara \& Mohammad, Jihad \& Ramayah, T.. (2017). Factors affecting consumers' intention to purchase counterfeit product: Empirical study in the Malaysian market. Asia Pacific Journal of Marketing and Logistics. 29. 00-00. 10.1108/APJML-09-2016-0169.

Rahmaningtyas, A., Hartono, S., \&amp; Suryantini, A. (2017). Factors Affecting Online $\begin{array}{lllll}\text { Purchasing Of Local Food. Agro Ekonomi, } 189 . & \end{array}$ https://doi.org/10.22146/jae.26129

Ramadhani, Y. F. (n.d.). PENGARUH INOVASI PRODUK DAN HARGA TERHADAP NIAT BELI MASKER MUSTIKA RATU (STUDI PADA PENGUNJUNG GIANT HYPERMARKET DI SURABAYA). PENGARUH INOVASI PRODUK DAN HARGA TERHADAP NIAT BELI MASKER MUSTIKA RATU (STUDI PADA PENGUNJUNG GIANT HYPERMARKET DI SURABAYA) | Jurnal Ilmu Manajemen (JIM). https://ejournal.unesa.ac.id/index.php/jim/article/view/22302.

Ridder, P. by M., \&amp; 23, N. (2020, November 23). Face masks: forecasted market value worldwide 2018-2025. Statista. https://www.statista.com/statistics/857025/globalfacial-masks-market-value/.

Román, S., \&amp; Cuestas, P. J. (2008). The Perceptions of Consumers Regarding Online Retailers' Ethics and Their Relationship with Consumers' General Internet Expertise and Word of Mouth: A Preliminary Analysis. Journal of Business Ethics, 83(4), 641656. https://doi.org/10.1007/s10551-007-9645-4 
Volume 3 Issue 9 (September 2021) PP. 67-90 DOI 10.35631/AIJBES.39006

Román, S., \&amp; Cuestas, P. J. (2008). The Perceptions of Consumers Regarding Online Retailers' Ethics and Their Relationship with Consumers' General Internet Expertise and Word of Mouth: A Preliminary Analysis. Journal of Business Ethics, 83(4), 641656. https://doi.org/10.1007/s10551-007-9645-4

Saldaña Johnny, Saldaña Johnny, \&amp; Miles, M. B. (2013). The coding manual for qualitative researchers qualitative data analysis: a methods sourcebook. Sage Publications.

Satriawan, K. A. (2020). The role of purchase intention in mediating the effect of perceived price and perceived quality on purchase decision. International Research Journal of Management, IT and Social Sciences. https://doi.org/10.21744/irjmis.v7n3.887

Scott, C., \&amp; Medaugh, M. (2017). Axial Coding. The International Encyclopedia of Communication Research

Methods,

$1-2$. https://doi.org/10.1002/9781118901731.iecrm0012

Sharma, P., \&amp; Chan, R. Y. K. (2011). Counterfeit proneness: Conceptualisation and scale development. Journal of Marketing Management, 27(5-6), 602-626. https://doi.org/10.1080/0267257x.2010.489829

Sharma, P. (2010). Country of origin effects in developed and emerging markets: Exploring the contrasting roles of materialism and value consciousness. Journal of International Business Studies, 42(2), 285-306. https://doi.org/10.1057/jibs.2010.16

Sharma, P. (2011). Demystifying Cultural Differences in Country-of-Origin Effects: Exploring the Moderating Roles of Product Type, Consumption Context, and Involvement. Journal of International Consumer Marketing, 23(5), 344-364. https://doi.org/10.1080/08961530.2011.602952

Sharma, P., \&amp; Chan, R. Y. K. (2016). Demystifying deliberate counterfeit purchase behaviour. Marketing Intelligence \&amp; Planning, 34(3), 318-335. https://doi.org/10.1108/mip-12-2014-0228

Singh, L. R., \& Sahni, S. K. (2019). Materialism as Predictor of Purchase Intention towards Counterfeit Products: A Conceptual Framework $\dagger$. IUP Journal of Management Research, 18(1), 53.

Souiden, N., \&amp; Diagne, M. (2009). Canadian and French men's consumption of cosmetics: a comparison of their attitudes and motivations. Journal of Consumer Marketing, 26(2), 97-109. https://doi.org/10.1108/07363760910940465

Sparks, J. R., \&amp; Pan, Y. (2009). Ethical Judgments in Business Ethics Research: Definition, and Research Agenda. Journal of Business Ethics, 91(3), 405-418. https://doi.org/10.1007/s10551-009-0092-2

Strauss, A. L. (1987). Qualitative analysis for social scientists.NewYork:CambridgeUniversityPress. doi:10.1017/CBO9780511557842

Strauss, A. L., \&amp; Corbin, J. M. (1991). Basics of qualitative research grounded theory procedures and techniques. Sage Publ.

Stöttinger, B., \&amp; Penz, E. (2015). Concurrent Ownership of Brands and Counterfeits: Conceptualization and Temporal Transformation from a Consumer Perspective. Psychology \&amp; Marketing, 32(4), 373-391. https://doi.org/10.1002/mar.20786

Sugiyono. (2013). Metode Penelitian Pendidikan Pendekatan Kuantitaif, Kualitatif, Dan R\&D. Metode Penelitian Pendidikan Pendekatan Kuantitaif, Kualitatif, Dan R\&D. Https://Doi.Org/10.1007/S13398-014-0173-7.2

Sukato, N., \& Elsey, B. (2009). A model of male consumer behaviour in buying skin care products in Thailand. ABAC Journal, 29(1), 39-52. http://its3.au.edu/open_journal/index.php/abacjournal/article/view/527\%5Cnhttp://www.journ al.au.edu/abac_journal/2009/jan09/article03_JanApr2009.pdf 
Volume 3 Issue 9 (September 2021) PP. 67-90 DOI 10.35631/AIJBES.39006

Taylor, S., \&amp; Todd, P. A. (1995). Understanding Information Technology Usage: A Test of Competing Models. Information Systems Research, 6(2), 144-176. https://doi.org/10.1287/isre.6.2.144

Tephaniec. (2020, October 12). Ingin Muka Cerah Alami? Ini 5 Rekomendasi Masker Organik Terbaik. IDN Times. https://www.idntimes.com/life/women/tephaniec/rekomendasimasker-organik-c1c2/5.

Tobias, R. D. (1995). An introduction to partial least squares regression. SAS Conference Proceedings: SAS Users Group International 20 (SUGI 20). https://doi.org/http://support.sas.com/techsup/technote/ts509.pdf

Toor, A., Husnain, M., \& Hussain, T. (2017). The Impact of Social Network Marketing on Consumer Purchase Intention in Pakistan: Consumer Engagement as a Mediator. Asian Journal of Business and Accounting, 10(1), 167-199. Retrieved from https://ajba.um.edu.my/article/view/3478

Venkatesh, V., Morris, M. G., \&amp; Ackerman, P. L. (2000). A Longitudinal Field Investigation of Gender Differences in Individual Technology Adoption DecisionMaking Processes. Organizational Behavior and Human Decision Processes, 83(1), 33-60. https://doi.org/10.1006/obhd.2000.2896

Vitell, S. J., \&amp; Hunt, S. D. (n.d.). The general theory of marketing ethics: the consumer ethics and intentions issues. Handbook on Ethics and Marketing, 15-37. https://doi.org/10.4337/9781781003435.00009

Vollstedt, M., \&amp; Rezat, S. (2019). An Introduction to Grounded Theory with a Special Focus on Axial Coding and the Coding Paradigm. ICME-13 Monographs Compendium for Early Career Researchers in Mathematics Education, 81-100. https://doi.org/10.1007/978-3-030-15636-7_4

Wall, A.P. (2007). Government 'demarketing' as viewed by its target audience. Marketing Intelligence \& Plan-ning, 25 (2), pp. 123-125.

Wathoni, N., Haerani, A., Yuniarsih, N., \&amp; Haryanti, R. (2018). A Review On Herbal Cosmetics In Indonesia. International Journal of Applied Pharmaceutics, 10(5), 13. https://doi.org/10.22159/ijap.2018v10i5.28102

Wilcox, K., Kim, H. M., \&amp; Sen, S. (2009). Why Do Consumers Buy Counterfeit Luxury Brands? Journal of Marketing Research, 46(2), 247-259. https://doi.org/10.1509/jmkr.46.2.247

Wong, K. K. K.-K. (2013). 28/05 - Partial Least Squares Structural Equation Modeling (PLSSEM) Techniques Using SmartPLS. Marketing Bulletin, 24(1), 1-32. Retrieved from http://marketingbulletin.massey.ac.nz/v24/mb_v24_t1_wong.pdf\%5Cnhttp://www.res earchgate.n et/profile/Ken_Wong10/publication/268449353_Partial_Least_Squares_Structur al_Equation_Modeling_(PLSSEM)_Techniques_Using_SmartPLS/links/54773b1b0cf 293e2da25e3f3.pdf

Xia, B. S., \& Gong, P. (2014). Review of business intelligence through data analysis. Benchmarking, 21(2), 300-311. https://doi.org/10.1108/BIJ-08-2012-0050

Xu, Y., Summers, T. A., \&amp; Belleau, B. D. (2004). Who buys American alligator? Journal of Business Research, 57(10), 1189-1198. https://doi.org/10.1016/s01482963(02)00327-2

Yang, H., \&amp; Morgan, S. L. (2011). Introduction to strategy, corporate governance and corporate reform. Business Strategy and Corporate Governance in the Chinese Consumer Electronics Sector, 1-21. https://doi.org/10.1016/b978-1-84334-6562.50001-6 
Volume 3 Issue 9 (September 2021) PP. 67-90 DOI 10.35631/AIJBES.39006

Yellapu, Vikas. (2018). Descriptive statistics. International Journal of Academic Medicine. 4. 60.10.4103/IJAM.IJAM_7_18. https://www.researchgate.net/publication/327496870 _Descriptive_statistics 